\title{
Pengembangan Virtual Reality untuk Promosi Wisata Religi Pura Ponjok Batu
}

\section{Komang Yudi Purnawan ${ }^{1 *}$, Dewa Gede Hendra Divayana ${ }^{2}$, I Gede Partha Sindu ${ }^{3}$}

${ }^{123}$ Jurusan Pendidikan Teknik Informatika/FTK, Universitas Pendidikan Ganesha Singaraja, Indonesia

\section{A R T I C L E I N F O}

Article history:

Received 19 January 2019

Received in revised form

10 February 2019

Accepted 12 March 2019

Available online 25 April

2019

Kata Kunci:

Virtual Reality, Promosi,

Pura Ponjok Batu, Waterfal,

Cardboard

Keywords:

Virtual Reality, Promotion,

Ponjok Batu Temple,

Waterfal, Cardboard

\begin{abstract}
A B S T R A K
Pura merupakan salah satu bangunan penting bagi umat Hindu Bali yang dikenal memiliki kehidupan religius yang tinggi. Salah satu Pura yang menjadi objek Wisata Religi yang terletak di Bali utara yaitu Pura Ponjok Batu.Berdasarkan hasil wawancara yang dilakukan dengan petugas dari Dinas Pariwisata Kabupaten Buleleng dan bapak Kadek Pasek salah satu petugas jaga di Pura Ponjok Batu mengatakan, Kurangnya Minat wisatawan untuk berkunjung ke Pura Ponjok Batu.Penelitian ini bertujuan untuk mengembangkan Virtual Reality sebagai media Promosi Wisata Religi Pura Ponjok Batu yang terletak di Kabupaten Buleleng. Langkah-langkah dalam mengembangkan Virtual Reality ini terdiri dari 3 langkah. Pertama mengambil Gambar asli Pura dengan menggunakan drone, camera. Langkah kedua yaitu pengembangan objek 3D Pura dengan menggunakan Blender. Langkah ketiga adalah pengembangan aplikasi dengan menggunakan Unity serta alat VR yang digunakan adalah Smartphone dan Carboard. Penelitian ini menggunakan metode SDLC Waterfall. Pengujian pada penelitian ini menggunakan 4 tahapan proses pengujian: (1) uji blackbox dengan 5 responden didapat hasil tidak terdapat kesalahan, (2) Uji ahli media dengan 2 responden dinyatakan sudah sesuai, (3) Uji ahli isi dengan 2 responden dinyatakan sudah sesuai, (4) Uji UEQ (User Experience Quistionnaire) di dapat persentase rata-rata dari 20 responden dengan hasil positif.
\end{abstract}

A B S T R A C T

The temple is one of the important buildings for Balinese Hindus who are known to have a high religious life. One of the temples that are the object of religious tourism located in northern Bali is Ponjok Batu Temple. Ponjok Batu Temple. This research aims to develop Virtual Reality as a media for the Promotion of Ponjok Batu Religious Tourism, located in Buleleng Regency. The steps in developing Virtual Reality consist of 3 steps. First take the original image of the temple using a drone, camera. The second step is developing 3D Pura objects using Blender. The third step is application development using Unity and the VR tools used are Smartphone and Carboard. This research uses SDLC Waterfall method. Testing in this study uses 4 stages of the testing process: (1) a blackbox test with 5 respondents found no error results, (2) A media expert test with 2 respondents was declared appropriate, (3) A content expert test with 2 respondents was declared appropriate, (4) The UEQ (User Experience Quistionnaire) Test obtained an average percentage of 20 respondents with positive results.

\footnotetext{
* Corresponding author.

E-mail addresses: purnawanyudixx@gmail.com (I Komang Yudi Purnawan)
} 


\section{Pendahuluan}

Pulau Bali tidak dapat dipisahkan dengan berbagai kebudayaan dan kesenian yang dimilikinya. Kebudayaan yang khas dimiliki oleh pulau Bali salah satunya adalah Pura.Pura merupakan salah satu bangunan penting bagi umat Hindu Bali yang dikenal memiliki kehidupan religius yang tinggi. Masyarakat Bali selalu menempatkan pura di tempat yang utama atau di tempat yang menurut aturan yang berlaku sesuai dengan nilai-nilai spiritual umat Hindu [1]. Keindahan dan kesakralan Pura menjadi hal yang sangat menarik bagi wisatawan, ditambah dengan keindahan alam di sekitar area Pura dan tidak jarang pula, Pura sering dijadikan sebagai objek Wisata Religi, namun dengan tetap dijaga kesakralannya.

Wisata Religi merupakan salah satu jenis wisata yang berkaitan erat dengan sisi religius atau keagamaan yang dianut oleh umat manusia. Wisata religi dimaknai sebagai kegiatan wisata ke tempat yang memiliki makna khusus bagi umat beragama, biasanya beberapa tempat ibadah yang memiliki kelebihan. Kelebihan ini misalnya dilihat dari sisi sejarah, adanya mitos dan legenda mengenai tempat tersebut, ataupun keunikan dan keunggulan arsitektur bangunannya. Salah satu Pura yang menjadi objek wisata Religi yang terletak di Bali utara yaitu Pura Ponjok Batu.

Pura Ponjok Batu merupakan salah satu Penyungsungan Jagat atau Pura Dang Kahyangan, Pura ini terletak di Desa Julah, Kecamatan Tejakula, Kabupaten Buleleng. Pura Ponjok Batu memiliki salah satu Icon yaitu adanya batu yang berbentuk perahu di pesisir pantai yang di sakralkan dan di percaya oleh masyarakat memiliki kekuatan mistis untuk melindungi para nelayan dalam mencari mata pencarian utamanya yaitu mencari ikan, Batu berbentuk perahu ini hanya bisa di temukan di Pura Ponjok Batu hal ini merupakan salah satu keunikan dari pura tersebut karena hanya terdapat di Pura Ponjok Batu dan tidak dapat ditemukan di Pura lainnya yang ada di Bali. Selain Icon batu yang berbentuk perahu, adapula sarkofagus yang ditemukan pada saat penggalian di lokasi perbaikan Pura. Berdasarkan proses ditemukannya sarkofagus ini ditemukan di areal Pura Ponjok Batu yang merupakan areal suci pada saat melakukan pemugaran Pura [2].

Berbagai upaya yang dilakukan pemerintah dalam promosi Pura Ponjok Batu, seperti halnya yang dilakukan Dinas Pariwisata Kabupaten Buleleng yaitu pembuatan pamflet video dan foto yang tersebar di jerjaring sosial namun, upaya promosi belum optimal, masih kurangnya minat wisatawan untuk berkunjung ke Pura Ponjok Batu dengan strategi promosi pariwisata masih sangat kurang untuk menarik minat wisatawan untuk berkunjung ke Pura Ponjok Batu dan mengetahui bangunan suci serta peninggalan Sejarah Pura Ponjok Batu. Pura Ponjok Batu ini belum begitu ramai dikunjungi oleh wisatawan dibandingkan dengan Pura yang berada diobyek-obyek wisata lainnya, karena jarak tempuhnya yang cukup jauh dari pusat kota.Berdasarkan hasil wawancara, penelitian ini bertujuan untuk menambah minat wisatawan untuk berkunjung ke pura Ponjok Batu yang dilakukan dengan dibuatnya sebuah media promosi dengan memanfaatkan teknologi Virtual Reality untuk Promosi Wisata Religi Pura Ponjok Batu. Teknologi Virtual Reality memungkinkan pengguna untuk dapat berinteraksi di dunia Virtual sehingga seolah-olah berada di lingkungan tersebut. Contoh teknologi Virtual Reality yang cukup sederhana adalah Google Cardboard, dengan menggunakan Google Cardboard pengguna akan merasakan pengalaman Virtual Reality dengan cara menggunakan smartphone yang memiliki sensor gvroscope dengan Google Cardboard [3].

\section{Metode}

\section{a. Jenis dan Model Penelitian}

Pengembangan Aplikasi Virtual Reality Untuk Promosi Wisata Religi Pura Ponjok Batu 3D ini termasuk penelitian pengembangan Research and Development .Penelitian Research and Development adalah metode penelitian yang digunakan untuk menghasilkan produk tertentu dan menguji keefektifan produk tersebut. Metode penelitian ini menekankan kemampuan penelitian dalam membuat suatu produk baik berupa materi, media, alat dan strategi pembelajaran atau maupun rekayasa pendidikan. Model yang digunakan dalam penelitian ini adalah Waterfall.

\section{b. Model Pengembangan}

Pengembangan Virtual Reality untuk Promosi Wisata Religi Pura Ponjok Batu ini menggunakan siklus hidup pengembangan perangkat lunak SDLC (Software Development Life Cycle) dalam bentuk sekuensial linear atau model air terjun (Waterfall). Metode SDLC model waterfall merupakan suatu proses pengembangan perangkat lunak yang berurutan, dimana setiap tahap harus diselesaikan terlebih dahulu sebelum memasuki tahap berikutnya yang dilihat sebagai aliran air yang terus mengalir melewati tahaptahap yang ada yaitu tahapan Analisis, Desain, Kode dan Tes [6].dapat dilihat pada Gambar 2. 


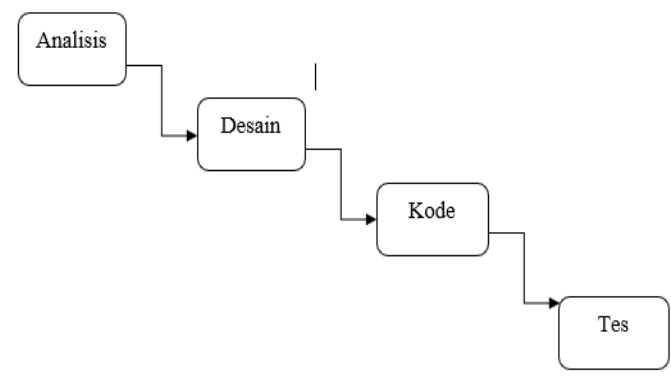

Gambar 1. Tahapan Waterfall pada Aplikasi yang dikembangkan

Tahap pertama dari model Waterfall adalah tahap analisis, Tahap ini merupakan pengumpulan informasi dan kebutuhan secara lengkap kemudian dianalisis kemudian dianalisis dan didefinisikan kebutuhan yang harus dipenuhi oleh aplikasi yang akan dibangun. Pada tahap ini dilakukan sebuah analisis masalah, analisis kebutuhan yang meliputi kebutuhan fungsional dan non fungsional.

Tahap kedua adalah tahap desain Tahapan ini merupakan tahapan membuat rancangan dari aplikasi. Pada pengembangan Virtual Reality untuk Promosi Wisata Religi Pura Ponjok Batu ini, telah di rancang model fungsional perangkat lunak, bataan perancangan perangkat lunank, perancangan scenario aplikasi, dan perancangan antarmua perangkat lunak

Tahap Implementation Tahapan ini merupakan tahapan implementai aplikasi yang di implementasikan ke masyarakat umum, Dinas Pariwisata Kabupaten Buleleng dan Manajemen Operasional Kawasan Pura Ponjok batu

Tahapan selanjutnya dari pengembangan aplikasi Virtual Reality Untuk Promosi Wisata Religi Pura Ponjok Batu. Adalah tahap testing Tahapan ini merupakan tahapan untuk mengetahui kekurangan dan kelemahan maupun kelahan dari aplikasi yang dikembangkan, sehingga aplikai masih bisa di perbaiki untuk mengurangi kesalahan-kesalahan yang terjadi sebelum aplikai di rilis ke masyarakat luas (pengguna). Pada tahap testing akan dilakukan 4 jenis pengujian yaitu Uji Blackbox,Uji Ahli Media, Uji Ahli Isi, dan Uji respon pengguna

\section{Hasil dan pembahasan}

\section{A. Hasil Tahap Analyze}

Hasil yang didapatkan pada tahap analisis ini adalah teknologi Virtual Reality dapat digunakan sebagai media promosi untuk membantu menambah minat wisatawan untuk berkunjung ke pura Ponjok Batu,dengan penerapan Aplikasi Virtual reality Untuk promosi wisata religi Pura Ponjok Batu

Berdasarkan analisis masalah dan solusi, pada pengembangan aplikasi Virtual Reality

Untuk Promosi Wisata Religi Pura Ponjok Batu didapatkan beberapa kebutuhan fungsional sebagai berikut, yaitu:

1. Aplikasi dapat menampilkan menu utama aplikasi. Adapun bagian dari main menu, yaitu Mulai jelajah, Tentang, dan Keluar.

2. Aplikasi mampu menampilkan objek 3D Ruang lingkup visualisasi letak bangunan yaitu Jaba Sisi, Jaba Tengah dan Pantai..

3. Aplikasi mampu menampilkan informasi tentang objek bangunan yang di pilih Pengguna dapat melihat skor tertinggi game di aplikasi

4. Aplikasi mampu menampilkan informasi tentang identitas pengembang.

5. Aplikasi mampu menampilkan perintah keluar dari aplikasi.

Selain itu, terdapat juga beberapa kebutuhan non fungsional dari aplikasi. Kebutuhan non fungsional tersebut yaitu:

1. Usability

Aplikasi memiliki rancangan antarmuka perangkat lunak yang user friendly Agar Wisatawan bisa tertarik

2. Performance

Aplikasi berjalan pada perangkat dengan sistem operasi Android minimal versi 6.0 (Marshmallow) dan memiliki sensor gyroscope dan Sensor Accelorometer

3. Data Integrity

Arsitektur bangunan yang dibuat dalam aplikasi ini sesuai dengan tata letak bangunan Pura Ponjok Batu 


\section{Efficiency}

Aplikasi dapat berjalan pada smartphone Android dengan penyimpanan ruangan / storage menengah kebawah dimana yang dibutuhkan hanya $500 \mathrm{mb}$ untuk keseluruhan aplikasi ini

\section{B. Hasil Tahap Design}

Model fungsional perangkat lunak digunakan untuk mentranslasi kebutuhan perangkat lunak ke representasi desain agar dapat diimplementasikan menjadi program pada tahap selanjutnya diperlukan diagram. Pengembangan aplikasi ini, peneliti menggunakan dua macam diagram yaitu use case diagram, dan activity diagram.

\section{Use Case Diagram}

Use Case Diagram merupakan diagram yang menggambarkan actor (pengguna atau sistem lain), use case (deskripsi fungsi dari sebuah sistem) dan relasinya [7]. Use Case Diagram Pengembangan Virtual Reality untuk Promosi Wisata Religi Pura Ponjok Batu dapat dilihat pada Gambar 3

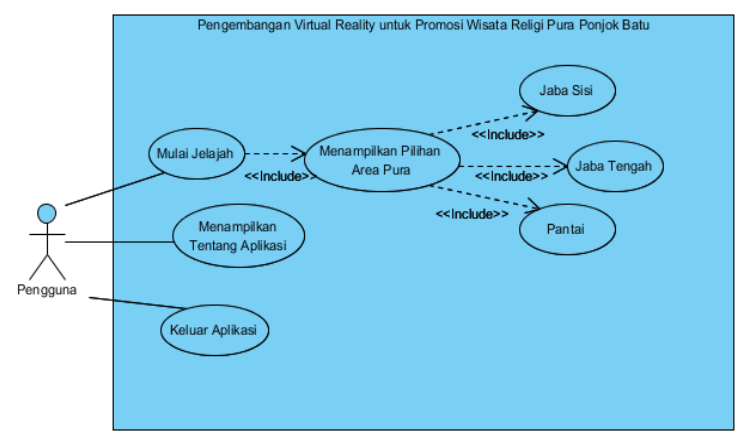

Gambar 2. Use Case Diagram Aplikasi

\section{Activity Diagram}

Activity diagram menggambarkan berbagai alur aktivitas dalam sistem yang sedang dirancang, bagaimana masing-masing alir berawal, decision yang mungkin terjadi, dan bagaimana mereka berakhir [7]. Berikut adalah activity diagram yang ada pada aplikasi Virtual Reality Pura Ponjok Batu yang meliputi menampilkan objek 3D Pura Ponjok Batu, menampilkan informasi pengembang, dan keluar dari aplikasi.

a. Activity diagram memulai Jelajah.

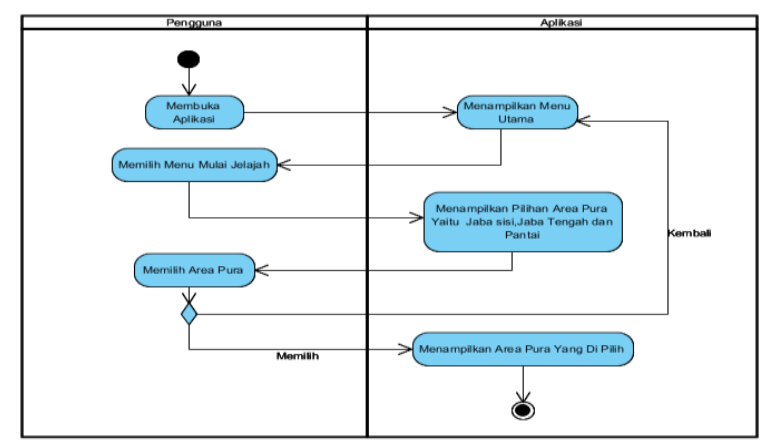

Gambar 3. Activity diagram memulai jelajah

Gambar activity diagram mulai jelajah menunjukkan proses pemilihan menu mulai pada aplikasi Virtual Reality untuk Promosi Wisata Religi Pura Ponjok Batu. Adapun langkah-langkah yang dilakukan, pengguna membuka aplikasi kemudian pada tampilan utama pilih menu mulai, akan tampil pembagian pura dari Pura Ponjok Batu. 
b. Activity diagam menampilkan tentang pengembang

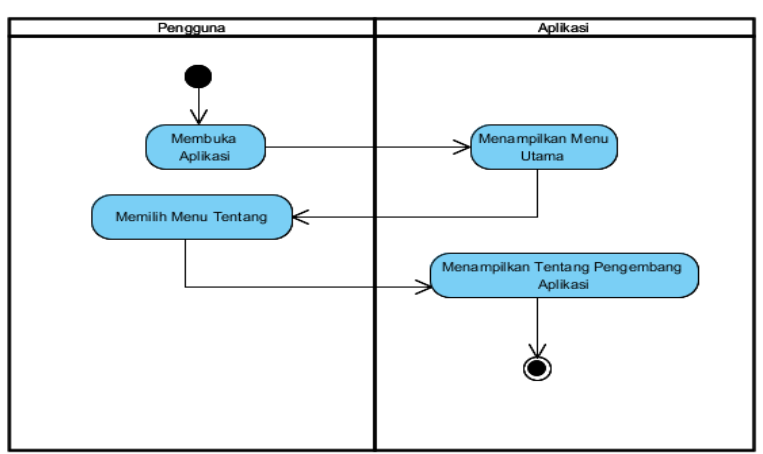

Gambar 4. Activity diagram Tentang

Gambar activity diagram tentang menunjukkan proses pada menu Tentang. Adapun langkahlangkah yang dilakukan, pengguna membuka aplikasi kemudian pengguna memilih menu Tentang. Menu Tentang menampilkan informasi mengenai biodata pengembang.

c. Activity diagram Keluar dari Aplikasi

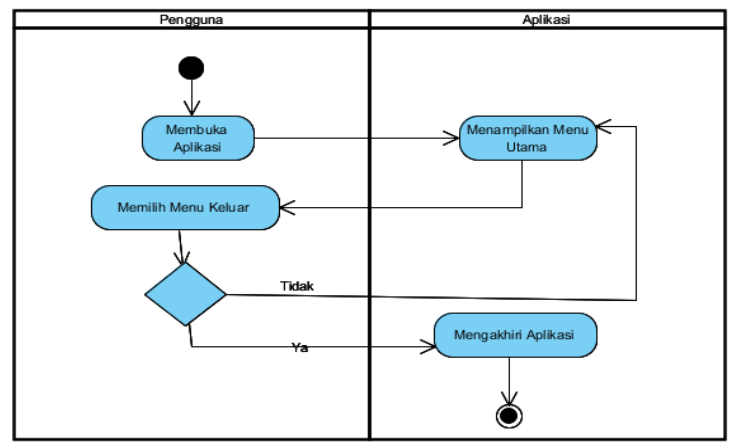

Gambar 5. Activity diagram Keluar

Gambar activity diagram Keluar menunjukkan proses pada menu Keluar Adapun langkah-langkah yang dilakukan, pengguna membuka aplikasi kemudian pengguna memilih menu Keluar. Menu Keluar berfungsi untuk keluar dari aplikasi.

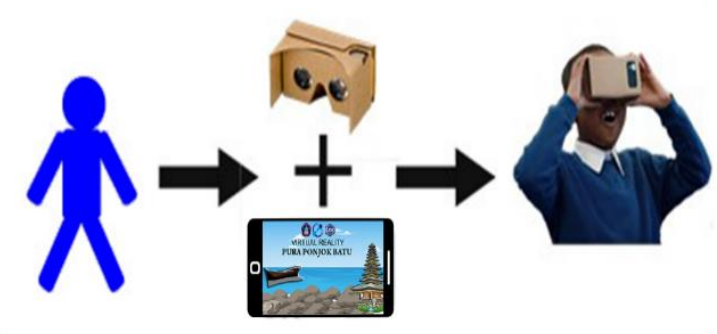

Gambar 6. Ilustrasi penggunaan Virtual Reality

Pada Gambar 7 dapat dilihat ilustrasi penggunaan asplikasi Virtual Reality untuk Promosi Wisata Religi Pura Ponjok Batu, dimana user harus menginstal aplikasi Virtual Reality di Smartphone Android yang mendukung dan pengguna harus menggunakan alat Carboad, setelah itu pengguna dapat menjelajah dan mengenal tata letak serta informasi bangunan Pura Ponjok Batu dalam mode Virtual Reality. 
3. Hasil Pengembangan Antarmuka Perangkat Lunak

Berikut adalah beberapa hasil pengembangan dari perancangan antarmuka aplikasi Virtual Reality Untuk Promosi Wisata Religi Pura Ponjok Batu berdasarkan perancangan antarmuka yang telah dilakukan pada tahap desain.

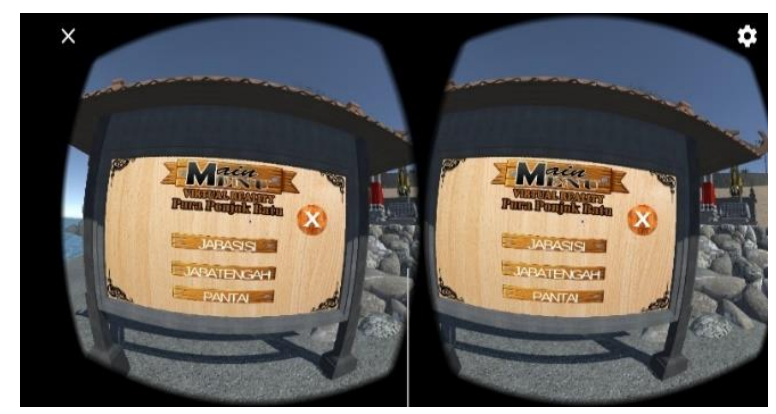

Gambar 7. Hasil antarmuka menu utama

Antarmuka ini menampilkan judul dari VR, dan beberapa tombol seperti tombol Mulai Jelajah,tentang, dan tombol untuk keluar dari aplikasi.

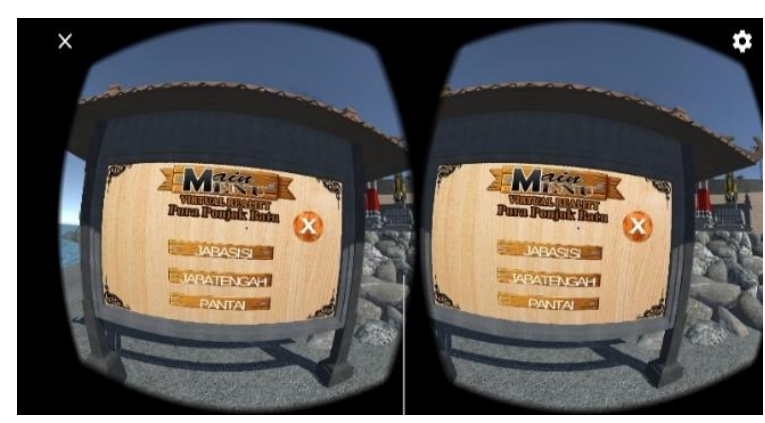

Gambar 8. Hasil antarmuka pilihan area pura

Tampilan antarmuka ini menampilkan pilihan Menu areal Pura Ponjok Batu. Pengguna bisa memilih salah satu menu areal Pura untuk melihat lingkungan dan bangunan apa saja yang ada di salah satu areal tersebut

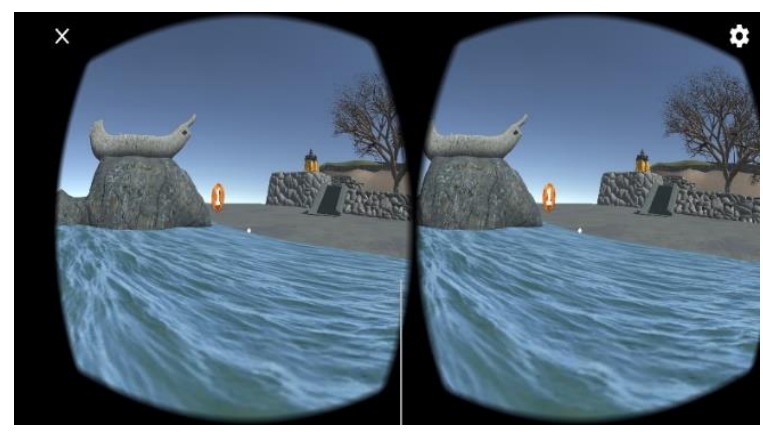

Gambar 9. Hasil Rancangan Antarmuka Mulai Jelajah

Tampilan antarmuka ini akan menampilkan ruang lingkup Pura Ponjok Batu 


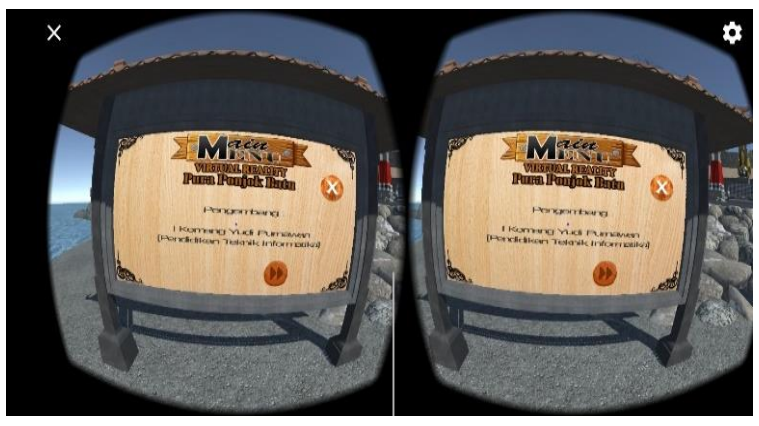

Gambar 10. Hasil Rancangan Antarmuka

Tentang

Tampilan antarmuka ini menampilkan informasi tentang pengembang yang berisi deskripsi mengenai pengembang.

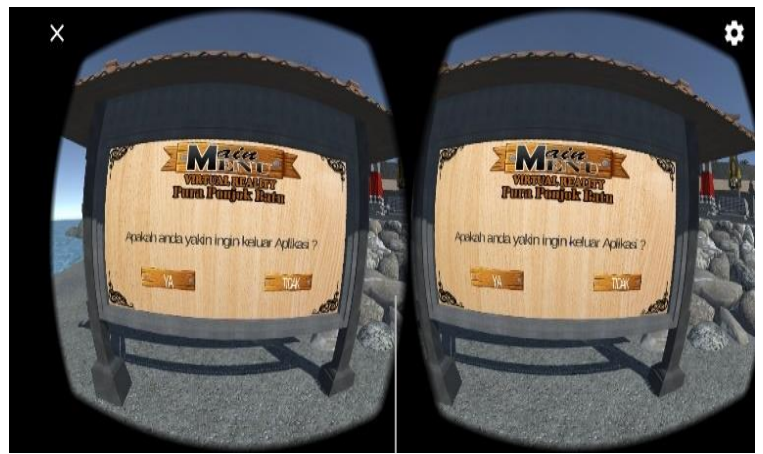

Keluar

Gambar 11. Hasil Rancangan Antarmuka

Tampilan antarmuka ini menampilkan pilihan "Apakah anda yakin akan keluar? " jika Ya maka akan keluar aplikasi dan jika tidak akan menuju ke Menu utama.

\section{Hasil Perancangan Skenario Aplikasi}

Skenario aplikasi merupakan alur penggunaan aplikasi dari awal menuju Main Play. Skenario disini digunakan agar aplikasi serasa lebih mudah untuk diarahkan sehingga tak melebar. Skenario digunakan peneliti sebagai alur penyampaian materi aplikasi kepada pengguna agar mudah dipahami. Skenario aplikasi Virtual Reality untuk Promosi Wisata Religi Pura Ponjok Batu dapat dilihat pada Tabel.

Tabel 1.Skenario Aplikasi

\begin{tabular}{ll}
\hline No & Penjelasan \\
\hline $\mathbf{1}$ & Pengguna memulai aplikasi Virtual Reality Pura Ponjok Batu \\
\hline $\mathbf{2}$ & $\begin{array}{l}\text { Pengguna akan masuk lingkungan tampilan menu utama dengan lingkungan Pesisir pantai Pura } \\
\text { Ponjok Batu. Dalam tampilan awal terdapat } 3 \text { Button menu utama antara lain Mulai Jelajah , } \\
\text { tentang, dan keluar. }\end{array}$ \\
\hline $\mathbf{3}$ & $\begin{array}{l}\text { Saat pengguna memilih menu button Mulai Jelajah maka akan ditampilkan scene dimana } \\
\text { pengguna bisa memilih pilihan areal Pura pada button yaitu Jaba sisi, Jaba Tengah dan Pantai. }\end{array}$ \\
& $\begin{array}{l}\text { Setelah memilih salah satu areal Pura maka aplikasi akan menampilkan pilihan areal Pura yang } \\
\text { dipilih misalnya Jaba Sisi yang akan menampilkan areal Jaba Sisi Pura Ponjok Batu yang berisi } \\
\text { bangunan pelinggih dan informasi pelinggih. Jika pengguna ingin mengetahui areal Jaba Tengah } \\
\text { maka dapat mengarahkan Pointer ke atas untuk memilih button Menu dan begitu juga jika } \\
\text { pengguna ingin mengetahui areal Pantai maka dapat memilih button menu Pantai. }\end{array}$ \\
\hline $\mathbf{4}$ & $\begin{array}{l}\text { Pada tampilan main menu, jika memilih menu button Tentang maka akan keluar popup yang } \\
\text { berisi identitas pengembangnya. }\end{array}$ \\
\hline $\mathbf{5}$ & Jika pengguna mengklik menu button Keluar pada main menu maka akan ditampilkan popup
\end{tabular}


Keluar aplikasi dengan pilihan Ya atau Tidak. Jika pengguna memilih softbutton Ya maka pengguna keluar dari aplikasi tapi jika pengguna menekan button Tidak maka pengguna akan kembali ke main menu dengan popup menghilang.

\section{Hasil Tahap Implementasi}

Pada tahap ini peneliti akan melakukan implementasi aplikasi Virtual Reality untuk Promosi Wisata Religi Pura Ponjok Batu. Aplikasi akan diimplementasikan kepada masyarakat umum, Dinas Pariwisata Kabupaten Buleleng dan Manajemen Operasional Pura Ponjok Batu. Adapun tahapan dalam melakukan implementasi aplikasi Virtual Reality untuk Promosi Wisata Religi Pura Ponjok Batu dapat dilihat pada Tabel berikut.

Tabel 2.Tahapan Implementasi Aplikasi

\begin{tabular}{ll}
\hline No & Penjelasan \\
\hline $\mathbf{1}$ & $\begin{array}{l}\text { Peneliti memperkenalkan aplikasi Virtual Reality Virtual Reality untuk Promosi Wisata Religi } \\
\text { Pura Ponjok Batu kepada Wisatawan }\end{array}$ \\
\hline $\mathbf{2}$ & $\begin{array}{l}\text { Peneliti menjelaskan tata cara menggunakan Virtual Reality Virtual Reality untuk Promosi } \\
\text { Wisata Religi Pura Ponjok Batu mulai dari membuka aplikasi, memilih menu, dan cara melihat } \\
\text { objek beserta informasinya. }\end{array}$ \\
\hline $\mathbf{3}$ & $\begin{array}{l}\text { Masyarakat/pengguna akan mencoba menggunakan aplikasi Virtual Reality Virtual Reality untuk } \\
\text { Promosi Wisata Religi Pura Ponjok Batu untuk melihat bangunan dan .informasi bangunan }\end{array}$ \\
\hline
\end{tabular}

\section{Hasil Tahap Testing}

Tahap testing dilakukan setelah tahap implementasi selesai. Tahap testing dilakukan dengan tujuan mengetahui kekurangan dan kelemahan maupun kesalahan (error) dari aplikasi yang dikembangkan, sehingga aplikasi masih bisa diperbaiki untuk mengurangi kesalahan-kesalahan yang terjadi sebelum aplikasi di rilis ke masyarakat luas. Pada tahap testing akan dilakukan 4 jenis pengujian yaitu Uji Blackbox, Uji Ahli Media, Uji Ahli Isi, dan Uji respon pengguna.

\section{Uji Blackbox}

Uji Black box ditujukan ke responden diluar peneliti. Tujuan adanya Black box testing pada aplikasi Virtual Reality untuk Promosi Wisata Religi Pura Ponjok Batu untuk mengetahui kebenaran proses pada aplikasi Virtual Reality untuk Promosi Wisata Religi Pura Ponjok Batu sesuai target yang ingin di capai. Dari hasil Uji Blackbox yang disebar menunjukkan bahwa, semua kebenaran proses dalam aplikasi sudah berjalan dengan baik.

\section{Uji Ahli Media}

Pengujian ahli media digunakan untuk mendapatkan kesimpulan apakah aplikasi sudah siap untuk dua uji coba ke lapangan. Pada uji ahli media dilakukan oleh 2 ahli pada bidangnya, karena mengampu mata kuliah yang berhubungan dengan bidang ini. Fokus penilaian pada uji ahli media ini adalah kesesuaian pemilihan jenis huruf, kesesuaian pemilihan ukuran huruf dan Audio agar tidak nois.

\section{Uji Ahli Isi}

Uji Ahli Isi ini bertujuan untuk mengetahui isi yang terkandung di dalam aplikasi dengan kesesuaian isi terhadapat tema yang diangkat. Peneliti melibatkan 2 ahli isi yaitu Jro Mangku Kaler salah satu Pemangku di pura Ponjok Batu dan Bapak Kadek Pasek salah satu petugas jaga di pura. Ahli tersebut peneliti libatkan sebagai ahli isi pada penelitian ini karena dianggap memiliki pengetahuan secara jelas tentang Pura Ponjok Batu. Dari hasil Uji Ahli Isi yang disebar menunjukkan bahwa, semua isi yang terkandung di dalam aplikasi dengan kesesuaian isi sudah sesuai.

\section{Uji Respon Pengguna}

Pengujian kepada pengguna digunakan untuk mengetahui tanggapan dari pengguna setelah menggunakan aplikasi. Uji respon pengguna akan dilakukan dengan pemberian angket. Adapun metode yang digunakan dalam uji respon pengguna untuk mengukur tingkat kepuasan pengguna yaitu User Experience Questionnaire (UEQ) yang merupakan suatu alat bantu pengolahan data survey terkait pengalaman pengguna yang mudah diaplikasikan, terpercaya dan valid, yang dapat digunakan untuk melengkapi data dari metode evaluasi lainnya dengan penilaian kualitas subjektif 
Uji respon pengguna dan uji user experience. Jumlah responden yang peneliti gunakan dalam pengujian respon ini adalah 20 orang :Uji respon Pengguna dilakukan dengan cara penyebaran angket. Hasil dari User Experience Quistionneir didapatkan dengan pengolah data berupa file excel yang dapat diunduh di www.ueq-online.org. Hasil yang diperoleh dari Uji user experience dapat dilihat pada Gambar 13.

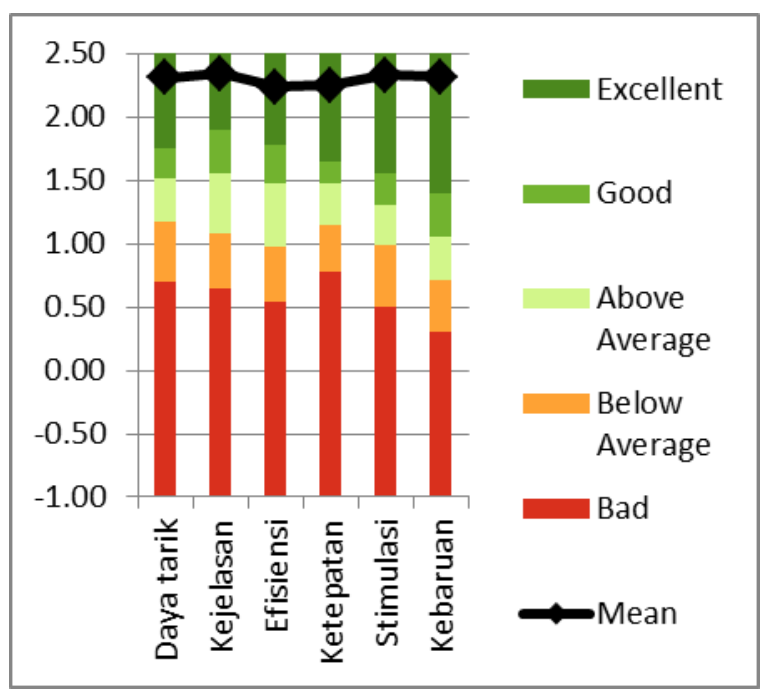

Gambar 12. Grafik hasil uji user experience

\section{Simpulan dan saran}

Pada penelitian ini telah dilakukan pengembangan Virtual Reality animasi 3 Dimensi untuk promosi wisata religi Pura Ponjok Batu menggunakan Blender dan Unity. Animasi yang dihasilkan sudah mencangkup semua bangunan dan pelinggih yang ada di Pura Ponjok Batu Berdasarkan hasil analisis, desain, implementasi dan pengujian pada penelitian Pengembangan Virtual Reality untuk Promosi Pura Ponjok Batu dapat ditarik kesimpulan yaitu aplikasi Virtual Reality untuk Promosi Pura Ponjok Batu mampu menampilkan bangunan dan pelinggih di Pura Ponjok Batu, menampilkan tata letak, nama bangunan dan pelinggih Pura Ponjok Batu, serta pengguna dapat mengetahui apa saja yang ada di Pura Ponjok Batu dengan merasakan suasana berada di Pura dengan berbasis Virtual. Pada pengujian aplikasi respon pengguna setelah menggunakan aplikasi Virtual Reality untuk Promosi Wisata Religi Pura Ponjok Batu mendapat respon yang sangat baik, mereka sangat tertarik dan antusias untuk mencoba aplikasi dengan mengenal bangunan dan pelinggih serta nama-namanya yang ada di Pura Ponjok Batu secara virtual yang seolah-olah berada di Pura Ponjok Batu. Dari hasil keseluruhan pengujian didapat hasil bahwa Aplikasi Virtual Reality untuk Promosi Wisata Religi Pura Ponjok Batu memiliki impresi positif berturut-turut dalam kelompok Daya tarik, Kejelasan, Efisiensi, Ketepatan, Stimulasi, dan Kebaruan. Respon pengguna yaitu masyarakat umum terhadap Virtual Reality untuk Promosi Wisata Religi Pura Ponjok Batu mendapat respon yang baik, mereka sangat tertarik dan antusias untuk mencoba aplikasi dengan mengenal bangunan dan pelinggih serta nama-namanya yang ada di Pura Ponjok Batu secara virtual yang seolah-olah berada di Pura Ponjok Batu.

Besar harapan aplikasi ini dapat dikembangkan dengan mempromosikan Wisata Religi lain yang ada di Bali karena selain Pura Ponjok Batu masih banyak Wisata Religi lain yang baik untuk di promosikan, seperti pura besakih yang di kenal dengan pusatnya pura yang ada di bali dan pura pura lain yang memiliki daya tarik tersendiri untuk menarik minat wisatawan untuk berkunjung.

\section{Daftar Rujukan}

Google. (2016, December 7). Google VR SDK for Unity. Retrieved from Google VR: https://developers.google.com/vr/android/.

Larman, C. (2005). Applying UML and Paterns (3rd Edition). New York: Pearson Education International.

Maharlika. (2011). Jurnal Waca Cipta Ruang Vol.II No.II Tahun 2010/2011 ISSN 2301-6507, (Ii). 
Mahayoni, Sendratari, \&Arta. (2017). TEJAKULA, BULELENG , BALI SEBAGAI SUMBER.

Pressman, R. S. (2002). Rekayasa Perangkat Lunak (Pendekatan Praktisi I). (C. Harnaningrum, Penerj.) Yogyakarta: Andi.

Riyadi, F. S. (2017). Aplikasi 3d virtual reality sebagai media pengenalan kampus politeknik negeri indramayu berbasis mobile, 2(2), 75-82. Retrieved from

Widyaningrum, I., Banjarnahor, D., \& Ginting, M. F. (2016). TOBA MUSEUM “Museum Berbasis Virtual Reality untuk Mempromosikan Kebudayaan Sumatera Utara." TOBA MUSEUM "Museum Berbasis Virtual Reality Untuk Mempromosikan Kebudayaan Sumatera Utara," 2(2), 733-740. Retrieved. 